\title{
Evaluation of combustion models for determination of refinery furnaces efficiency
}

\author{
Evaluación de modelos de combustión para la determinación \\ de la eficiencia en hornos de refinería
}

$\begin{array}{lll}\text { O. M. Cala } & \text { L. Meriño } & \text { V. Kafarov } \\ & & \text { J. Saavedra }\end{array}$

Recibido 19 de Noviembre de 2013, aceptado 1 de diciembre de 2014

Received: November 3, $2014 \quad$ Accepted: December 1, 2014

\begin{abstract}
The efficiency of combustion in furnaces is the measure of heat released in the flame absorbed by the fluid to be heated and is considered one of the most important variables when conducting studies on processes that occur in continuous process industries. The furnace efficiency is calculated using various mathematical models proposed in the literature; these models vary in complexity depending on the analyzed variables. The models I and II are based on the amount of energy absorbed by the furnace using the heating value, the model III contains variables such as air excess, stack gas temperature and adiabatic flame temperature, meanwhile the model IV contains heating losses in furnace's wall (2\%), the stack gas temperature and excess air. In this paper was used computer simulation to evaluate fuel gas mixtures with Lower Heating Values (LHV) between 800 to $2500 \mathrm{Btu} / \mathrm{ft}^{3}$, and they were compared with natural gas and data process; the results show that the combustion characteristics might change by varying the fuel composition. It was also found decreased combustion efficiency due to high hydrogen concentration; on the other hand the adiabatic flame temperature was increased in function of gas composition. Model IV presented in this research allowed evaluating combustion process efficiency using only two variables: stack gas temperature and the excess air.
\end{abstract}

Keywords: Efficiency, refinery gas, combustion, furnaces, fuel gas.

\section{RESUMEN}

La eficiencia de combustión en hornos es la medida del calor liberado en la llama que es absorbido por el fluido a calentar y es considerada una de las variables más importantes en la realización de estudios de los procesos que ocurren en una planta de proceso continuo. La eficiencia de un horno es calculada usando diferentes modelos matemáticos propuestos en la literatura, los cuales varían en su complejidad dependiendo de las variables analizadas. Los modelos I y II se basan en la cantidad de calor que es absorbida por el equipo fundamentados en el poder calorífico, el modelo III incluye variables como el exceso de aire, temperatura de chimenea y la temperatura adiabática de llama, mientras el modelo IV incluye pérdidas con las paredes del horno del $2 \%$, la temperatura de chimenea y el exceso de aire. Mediante simulación computacional fueron simuladas mezclas de gas combustible con poder calorífico inferior (LHV por sus siglas en inglés) entre 800-2500 BTU/pie ${ }^{3}$, y se compararon con el gas natural y con datos de proceso; encontrando que las características de la combustión cambian debido a la variación en la composición del combustible. Se presentó baja eficiencia debido a la alta concentración de hidrógeno y un aumento en la temperatura adiabática de llama en función de la composición del gas.

1 Centro de Investigación para el Desarrollo Sostenible en Industria y Energía (CIDES). Escuela de Ingeniería Química. Universidad Industrial de Santander. Cra 27 calle 9 ciudad universitaria. Bucaramanga, Colombia. E-mail: oscarcala20@hotmail.com; loumerino2@gmail.com; vkafarov@gmail.com

2 Instituto Colombiano del Petróleo-ECOPETROL, Km. 7 Vía a Piedecuesta, Piedecuesta, Colombia.

E-mail: Jaqueline.Saavedra@ecopetrol.com.co 
Finalmente el modelo IV permitió evaluar la eficiencia del proceso de combustión de forma efectiva, pues solamente utiliza la temperatura de chimenea y el exceso de aire.

Palabras clave: Eficiencia, gas de refinería, combustión, hornos, gas combustible.

\section{INTRODUCTION}

The refinery process of oil fractions faces major challenges due to the need of producing cleaner fuels that meet current environmental laws, especially those related to the increase of energy efficiency and contaminant emission reduction [1-2].

In the case of combustion of gaseous fuels, there is a wide variety of compounds that can be used in combustion processes depending on the source of origin and its availability. Since 1900 [3-5], studies were performed on the effects of changes in fuel supply to the burner and the effect that can generate in the efficiency of the combustion process. In general these studies have focused on the development of performance indexes to differentiate fuel gas performance tested in various combustion equipment.

In the petroleum industry, the recovered waste gas (refinery gas (RG)) contains high concentration of hydrogen, ethylene, propane and propylene, this gas is mixed with natural gas as an alternative fuel to curb the consumption of the natural gas (NG), however, the composition of gas can change widely depending of the unit of which was obtained. Therefore, it will have non homogeneous mixtures due to change in the composition fuel gas. These mixtures affect the heating value, the energy efficiency and pollution emissions. This also leads to coke formation on the tubes inner surface of the furnaces and structural damage by corrosion [6].

The refinery gas has been studied as an alternative to reduce energy costs; Hsieh [2] analyzed the influence of use hydrogen-rich fuel gas (50-80\% mole), the results showed that the emissions of $\mathrm{CO}_{2}$ and $\mathrm{NO}_{\mathrm{x}}$ can be reduced by 16.4 and $8.2 \%$ respectively [7], other studies analyzed the $\mathrm{NO}$ and $\mathrm{CO}_{2}$ emissions using different ratios: fuel gas/ hydrogen-rich refinery gas on medium-pressure boiler and high pressure cogeneration boiler, whose results showed a reduction in fuel-gas costs and greenhouse fume emissions emissions using refinery gas (RG) [8-9], these researches have considered the hydrogen like a clean fuel due to its heating value without pollutant generation [10]. In order to study the refinery gas is important to analyze parameters such as air excess, it affects the thermal efficiency and has environmental impacts generated by furnaces and boilers [11]. When the air excess is elevated, $\mathrm{O}_{2}$ concentration in the main combustion area is increased resulting in a rise of the flame temperature in the furnace. This also leads to temperature drop in the furnace radiation area that decreases the furnace efficiency [12]. The high temperature along with turbulent combustion in the furnace, causes reaction between oxygen and nitrogen, this leads to the formation of NO (nitric oxide) and $\mathrm{NO}_{2}$ (Nitrogen dioxide) [13]. In case of low air excess would lead to increasing furnace thermal efficiency, but could occur incomplete combustion due to lower $\mathrm{O}_{2}$ concentration [14], where is important to determinate the optimum oxygen value to use in any combustion process.

The researches aforementioned using refinery gas (RG) with high hydrogen content (50-80\% mole), but in the petrochemical industry such gases are produced in smaller quantities. Therefore, to successfully implement changes in terms of energy efficiency and reduction in the pollutant emission, it is necessary to analyze the effects of fuel gas composition in combustion equipment and the effect on efficiency of combustion, which is calculated by stack losses and the energy liberated from fuel used in the furnace.

This paper analyzes the general furnace combustion efficiency with the model proposed by ASME PTC 4.1 (Model I), the Siegert empirical model and other models proposed in the literature for simulating a combustion process using natural gas and refinery gas streams as fuel and calculating its efficiency. The results are compared with historical data of visbreaking process furnace to find a model that fits well to the real data, and establish a model that can reliably predict the furnace efficiency of a heater that used refinery gas as fuel. The evaluation of the combustion efficiency is a useful tool in the 
control and monitoring of the processes. It should be considered that models have limitations and that there are many variables that influence the process and thus it is important to take those considerations into account to improve furnace operation.

Heating furnace efficiency was evaluated using each of the proposed models in order to find a model that would best describes the operating conditions of a furnace in a refinery.

\section{THEORETICAL ANALYSIS}

\section{Models to calculate refinery furnaces efficiency}

Model I (equation (1)): Hsieh [2] used a basic model which used the input and output method (or indirect), described by ASME PTC 4.1 [15]. In this method the heating furnace efficiency is defined as:

$$
\eta=\frac{\text { Real heat absorbed by process }}{\text { Total heat credits of input fuel }} * 100
$$

Model II (equation (2)): Serrano and Carranza [14], presents a model that includes the higher heating value of fuel input to the process, besides the efficiency of the furnace is associated with that chemical energy can be converted into heating of the combustion products.

$$
\eta_{\text {comb }}=\frac{H H V-\left(H_{\text {Prod }}-H_{\text {Rea }}\right)}{H H V} * 100
$$

Where HHV is the higher heating value, $H_{\text {Prod }}$ is the enthalpy of the products and $H_{\text {Rea }}$ is the enthalpy of the reagents.

Model III: (equation (3)) Meza [16] analyzed the efficiency of combustion fuel gas in refinery furnaces cabin type; this model includes the excess oxygen and stack gas temperature and adiabatic flame temperature.

$$
\eta=97-\left(100 * \frac{21}{21-\% \text { exc }} * \frac{T_{\text {stack }}}{T_{\text {adia }}}\right)
$$

Where $T_{\text {stack }}$ is the stack gas temperature $\left({ }^{\circ} \mathrm{C}\right), T_{\text {adia }}$ is the adiabatic flame temperature $\left({ }^{\circ} \mathrm{C}\right)$ and $\%$ exc is the excess air.
Model IV: (equation (4)) A final model includes the heating losses in furnace's wall ( $2 \%$ is considered a good value for the design), besides the model use the excess oxygen and stack gas temperature.

$\eta=0,98-9,25 * 10^{-5} T_{\text {stack }}^{1,128}\left(1+\frac{\text { exc }_{\text {air }}}{100}\right)^{0,748}$

Where $T_{\text {stack }}$ is the stack gas temperature $\left({ }^{\circ} \mathrm{F}\right)$.

\section{EQUIPMENT}

In order to achieve the purpose of this research, a scaled fired heater representative from a petroleum refining process was selected. This one consists of a heat exchanger in which the process fluid flows within tubes and is heated by radiation from a combustion flame and by convection from the hot gases.

Fired heater consists in a closed steel array with an internal insulation of refractory bricks. The convective area is located in the upper side of the array and the stack. The radiation tubes are located over the walls and the flame is originated through the burners, the furnace analyzed in this work has 37 tubes in the convective and 49 tubes in the radiation area. Figure 1 shows an illustration of fired heater considered.

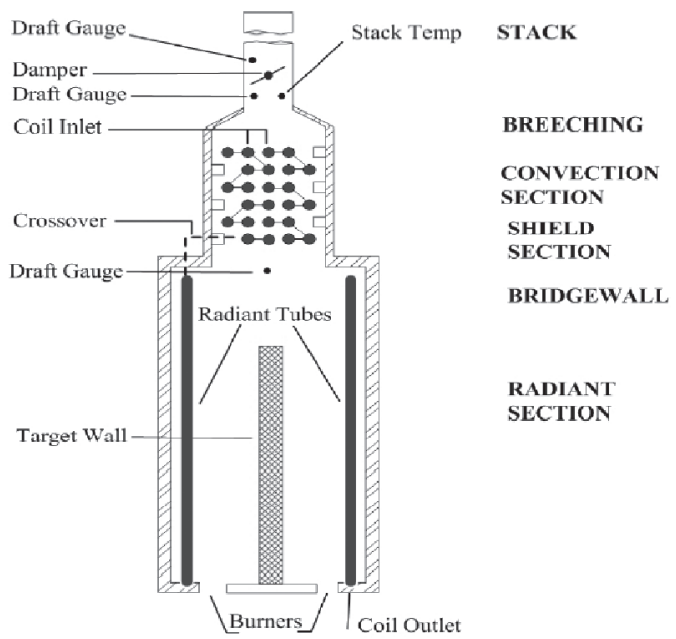

Figure 1. Illustration of fired heater [17].

\section{RESULTS AND DISCUSSION}

The review of historical process data includes measuring the flow or feet, record input and output 
pressure, inlet and outlet temperature, and skin tube temperature, as well as measuring the calorific value. This review of historical data took place during a two years period of analysis. Figure 2 shows fuel gas network in a refinery.

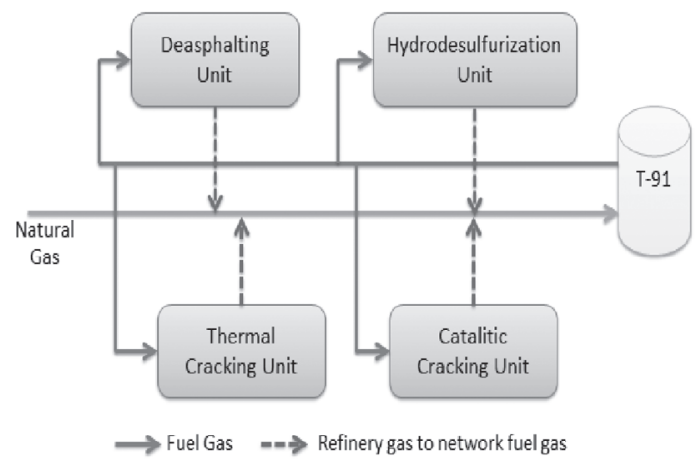

Figure 2. Fuel gas network.

Chromatographic data of streams identified as contributors to the combustible network were reviewed. Variability of the gas composition, the ranges of each of the identified compounds and analyzing the frequency deviation in the concentration was analyzed by StatGraphics Centuriun XV.II program. Fuel gas composition in a refinery could be a mixture of compounds shown in Table 1 .

Aspen Hysys 2006.5 was used for the simulation. This is specialized software for process simulation for chemical and petrochemical industries. Peng Robinson equation was selected as property package due to its high precision on gas, petroleum and petrochemical applications. Data on energy efficiency, temperature and flue gas compositions were obtained.

Based on the simulation scheme for the combustion process shown in Figure 3, fuel gas composition was changed according to a boundary set by statistical analysis. The process parameters are showed in Table 2.

Fuel gas stream of $1 \mathrm{kmol} / \mathrm{h}$ was used for refinery gas simulation and the air excess was changed according to oxygen excess $(n)$ since $n=0 \%$ (minimum or stoichiometric) to $\mathrm{n}=10 \%$ (maximum reported in

Table 1. Fuel gas composition.

\begin{tabular}{|c|c|c|c|c|c|c|c|}
\hline \multicolumn{2}{|c|}{ Compound } & \multirow{2}{*}{$\begin{array}{c}\text { C1 } \\
96.85\end{array}$} & \multirow{2}{*}{$\begin{array}{c}\text { C2 } \\
0\end{array}$} & \multirow{2}{*}{$\begin{array}{c}\text { C3 } \\
2.04\end{array}$} & \multirow{2}{*}{$\frac{\text { C4 }}{31.28}$} & \multirow{2}{*}{$\frac{\text { C5 }}{42.02}$} & \multirow{2}{*}{$\begin{array}{c}\begin{array}{c}\text { Natural } \\
\text { Gas }\end{array} \\
0.13 \\
\end{array}$} \\
\hline $\mathrm{CH}_{4}$ & Methane & & & & & & \\
\hline $\mathrm{C}_{2} \mathrm{H}_{6}$ & Ethane & 0.375 & 0.001 & 0.03 & 13.34 & 3.50 & 0.40 \\
\hline $\mathrm{C}_{3} \mathrm{H}_{8}$ & Propane & 0.051 & 25.49 & 0.033 & 1.94 & 1.22 & 8.48 \\
\hline $\mathrm{C}_{4} \mathrm{H}_{10}$ & n-Butane & 0 & 0.005 & 0.028 & 0.21 & 0.37 & 59.85 \\
\hline $\mathrm{C}_{4} \mathrm{H}_{10}$ & i-Butane & 0.014 & 0.253 & 0.011 & 0.55 & 0.62 & 30.30 \\
\hline $\mathrm{C}_{5} \mathrm{H}_{12}$ & n-Pentane & 0 & 0 & 0 & 0 & 0 & 0.21 \\
\hline $\mathrm{C}_{5} \mathrm{H}_{12}$ & i-Pentane & 0.074 & 0 & 0.038 & 1.46 & 0.01 & 0.51 \\
\hline $\mathrm{C}_{2} \mathrm{H}_{4}$ & Ethylene & 0.069 & 0 & 0 & 12.20 & 0.96 & 0.02 \\
\hline $\mathrm{C}_{3} \mathrm{H}_{6}$ & Propylene & 0 & 74.24 & 0 & 7.71 & 5.18 & 0.10 \\
\hline $\mathrm{C}_{4} \mathrm{H}_{8}$ & Butylene & 0.008 & 0 & 0 & 0 & 0 & 0 \\
\hline $\mathrm{H}_{2} \mathrm{~S}$ & $\begin{array}{l}\text { Hydrogen } \\
\text { sulfide }\end{array}$ & 0 & 0.011 & 0.061 & 3.11 & 0 & 0 \\
\hline $\mathbf{H}_{2}$ & Hydrogen & 0.77 & 0 & 97.38 & 17.21 & 34.72 & 0 \\
\hline $\mathrm{CO}_{2}$ & $\begin{array}{l}\text { Carbon } \\
\text { dioxide }\end{array}$ & 0 & 0 & 0.263 & 6.64 & 8.86 & 0 \\
\hline $\mathrm{N}_{2}$ & Nitrogen & 1.764 & 0 & 0.263 & 6.64 & 8.86 & 0 \\
\hline $\mathrm{O}_{2}$ & Oxygen & 0.025 & 0 & 0 & 0 & 0 & 0 \\
\hline
\end{tabular}

Table 2. Process parameters.

\begin{tabular}{|c|c|c|c|}
\hline Equipment & \multicolumn{2}{|c|}{$\begin{array}{c}\text { Temperature }\left[{ }^{\circ} \mathbf{C}\right] \\
\text { Inlet Outlet }\end{array}$} & $\begin{array}{c}\text { Pressure } \\
\text { [KPa] }\end{array}$ \\
\hline $\begin{array}{c}\text { Conversion reactor } \\
\text { CRV-101 }\end{array}$ & 32.22 & $\begin{array}{c}\text { Adiabatic flame } \\
\text { temperature }\end{array}$ & 101.4 \\
\hline Heater E-101 & $\begin{array}{c}\text { Adiabatic flame } \\
\text { temperature }\end{array}$ & 320 & 101.4 \\
\hline
\end{tabular}




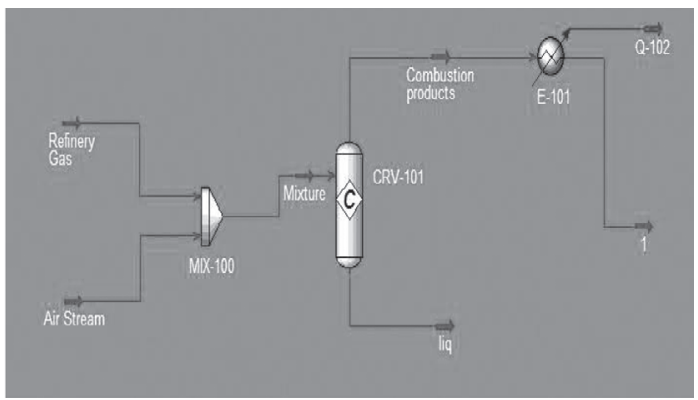

Figure 3. Simulation of combustion process using Aspen Hysys.

refinery industry). The heater outlet temperature was maintained on $320{ }^{\circ} \mathrm{C}$ (average stack temperature in a Colombian refinery).

The combustion reactions taking place in the conversion reactor and its lower heating value are shown below.

$$
\mathrm{CH}_{4}+2 \mathrm{O}_{2} \rightarrow \mathrm{CO}_{2}+2 \mathrm{H}_{2} \mathrm{O}+882,81 \mathrm{Btu} / \mathrm{ft}^{3}
$$

$2 \mathrm{C}_{2} \mathrm{H}_{6}+7 \mathrm{O}_{2} \rightarrow 4 \mathrm{CO}_{2}+6 \mathrm{H}_{2} \mathrm{O}+1580,96 \mathrm{Btu} / \mathrm{ft}^{3}$

$\mathrm{C}_{3} \mathrm{H}_{8}+5 \mathrm{O}_{2} \rightarrow 3 \mathrm{CO}_{2}+4 \mathrm{H}_{2} \mathrm{O}+2282,34 \mathrm{Btu} / \mathrm{ft}^{3}$

$n \mathrm{C}_{4} \mathrm{H}_{10}+\frac{13}{2} \mathrm{O}_{2} \rightarrow 4 \mathrm{CO}_{2}+5 \mathrm{H}_{2} \mathrm{O}+3003,21 \mathrm{Btu} / \mathrm{ft}^{3}$

$\mathrm{C}_{2} \mathrm{H}_{4}+3 \mathrm{O}_{2} \rightarrow 2 \mathrm{CO}_{2}+2 \mathrm{H}_{2} \mathrm{O}+1462,02 \mathrm{Btu} / \mathrm{ft}^{3}$

$$
\begin{aligned}
\mathrm{C}_{3} \mathrm{H}_{6}+\frac{9}{2} \mathrm{O}_{2} & \rightarrow 3 \mathrm{CO}_{2}+3 \mathrm{H}_{2} \mathrm{O}+2146,89 \mathrm{Btu} / \mathrm{ft}^{3} \\
2 \mathrm{H}_{2}+\mathrm{O}_{2} & \rightarrow 2 \mathrm{H}_{2} \mathrm{O}+265,40 \mathrm{Btu} / \mathrm{ft}^{3}
\end{aligned}
$$

Combustible mixtures were simulated by varying the composition of gas components, in order to have a representative refinery fuel for furnace. For the simulation were removed some components of the evaluated mixtures of refinery gas (RG) (i-penthane, butylene, acetylene, carbon monoxide, carbon dioxide, nitrogen and oxygen). The criteria used to reject these components were:

1. Find those compounds whose contribution to the stream concentration is very low $(<1 \%)$.

2. Compounds which are not present in most of the streams.

3. Compounds which do not contribute significantly to the heating value of the mixture.

In the case for n-butane and i-butane, only one representative compound of this gas family was selected based on the fact that represent the same lower heating value (LHV) and the same combustion reaction.

The statistical analysis done using software (Statgraphics Centuriun XV.II) allowed establishing eight main compounds (methane, ethane, propane, n-butane, ethylene, propylene, hydrogen sulfide and hydrogen) that form a representative gas in the combustion network. Then using Aspen Hysys to simulate the process it was possible to find four fuel mixtures that have LHV between $800 \mathrm{Btu} / \mathrm{ft}^{3}$ and $2000 \mathrm{Btu} / \mathrm{ft}^{3}$ (C1, C2, C3 and C4). Table 3 shows representative compositions fuel gas.

Table 3. Representative compositions of fuel gas.

\begin{tabular}{|c|c|c|c|c|c|c|}
\hline \multicolumn{2}{|c|}{ Compound } & C1 & C2 & C3 & C4 & Natural Gas (NG) \\
\hline $\mathbf{C H}_{\mathbf{4}}$ & Methane & 55 & 70 & 25 & 35 & 97 \\
\hline $\mathbf{C}_{\mathbf{2}} \mathbf{H}_{\mathbf{6}}$ & Ethane & 10 & 0 & 8 & 3 & 1 \\
\hline $\mathbf{C}_{\mathbf{3}} \mathbf{H}_{\mathbf{8}}$ & Propane & 0 & 16 & 25 & 35 & 1 \\
\hline $\mathbf{C}_{\mathbf{4}} \mathbf{H}_{\mathbf{1 0}}$ & n-butane & 4 & 5 & 10 & 12 & 0 \\
\hline $\mathbf{C}_{\mathbf{2}} \mathbf{H}_{\mathbf{4}}$ & Ethylene & 5 & 3 & 10 & 7 & 0,5 \\
\hline $\mathbf{C}_{\mathbf{3}} \mathbf{H}_{\mathbf{6}}$ & Propylene & 2 & 0 & 5 & 8 & 0,5 \\
\hline $\mathbf{H}_{\mathbf{2}} \mathbf{S}$ & $\begin{array}{c}\text { Hydrogen } \\
\text { sulfide }\end{array}$ & 4 & 1 & 2 & 0 & 0 \\
\hline $\mathbf{H}_{\mathbf{2}}$ & Hydrogen & 20 & 5 & 15 & 0 & 0 \\
\hline
\end{tabular}


Figure 4 shows the LHV values of the fuel mixtures and natural gas.

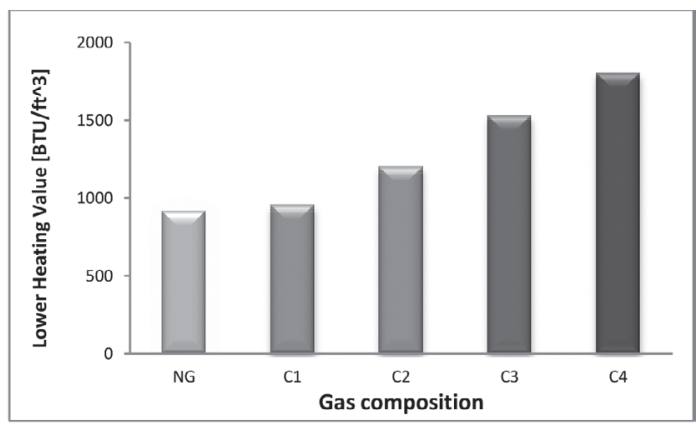

Figure 4. Lower heating values of fuel mixtures.

Figure 4 shows a wide range of lower heating value for RG, where the NG ranges from 850-1000 Btu/ $\mathrm{ft}^{3}$, in the case of RG two ranges were found. The first range RG scopes from $1000-1500 \mathrm{Btu} / \mathrm{ft}^{3}$ and second for higher values than $1500 \mathrm{Btu} / \mathrm{ft}^{3}$. The first case presented high composition of methane $(>50 \%)$ but hydrocarbons composition like ethane, ethylene, and hydrogen are increased, the second case presented lower methane composition $(<35 \%)$, but higher composition of propane and butane. Thus, we have a wide range of RG according to composition, which are used like fuel in the refineries. Accordingly, becomes important to validate their interchangeability and the impacts generated by fuel gas composition changes.

\section{Effect of use of refinery gas on the combustion process}

Air excess values among $0 \%$ to $10 \%$ were tested to establish the correlation between oxygen excess and the adiabatic flame temperature in order to evaluate the effect of the composition of the mixture on the adiabatic flame temperature.

Adiabatic flame temperature varied between $2030^{\circ} \mathrm{C}$ to $2110^{\circ} \mathrm{C}$ depending on the composition of fuel gas, to $0 \%$ air excess. Figure 5 shows the effect of the excess air percentage on adiabatic flame temperature for the four mixtures.

Process efficiency shows better results for $2 \%$ oxygen excess taking into account the variability of the fuel gas composition. This is in agreement with the industrial operating data.

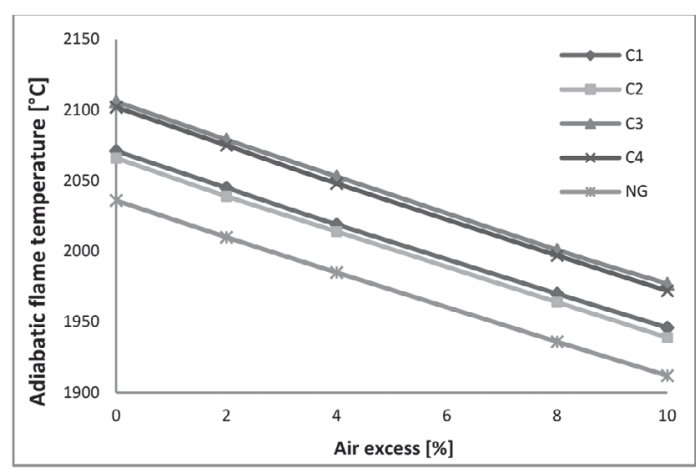

Figure 5. Effect of air excess percentage on adiabatic flame temperature.

The adiabatic flame temperature increase due to the changes of fuel gas composition, presents risks for the integrity of the equipment for high temperature damage; the mixtures with high content of propane and butane have a tendency to increase the adiabatic flame temperature. This is observed in Figure 5.

Results of the change in fuel gas composition are shown, stack gas temperatures affecting the environment and equipment, Table 4 shows variability between fuel gas composition and stack gas temperature.

Table 4. Data report of stack gas temperature.

\begin{tabular}{|c|c|c|}
\hline $\begin{array}{c}\text { Fuel gas } \\
\text { composition }\end{array}$ & $\begin{array}{c}\text { LHV } \\
\left(\mathbf{B T U}_{\mathbf{f} \mathbf{f t}^{\mathbf{3}}}\right)\end{array}$ & $\begin{array}{c}\text { Stack gas } \\
\left.\text { Temperature }^{(} \mathbf{C}\right)\end{array}$ \\
\hline 1 & 1131.90 & 471.11 \\
\hline 2 & 1068.10 & 454.44 \\
\hline 3 & 831.8 & 182.22 \\
\hline 4 & 862.8 & 196.11 \\
\hline 5 & 937 & 340.55 \\
\hline 6 & 1147.20 & 465.55 \\
\hline 7 & 860.1 & 196.11 \\
\hline 8 & 814.1 & 145 \\
\hline 9 & 1094.80 & 460 \\
\hline 10 & 1080.60 & 460 \\
\hline 11 & 893.6 & 207.22 \\
\hline 12 & 916.6 & 233.33 \\
\hline 13 & 1103.40 & 464.44 \\
\hline
\end{tabular}

Computer simulation using Aspen Hysys for different efficiency values shows that stack gas temperature decrease when the efficiency increases as a function of used oxygen excess. Figure 6 presents the relationship between efficiency and stack gas temperature. 


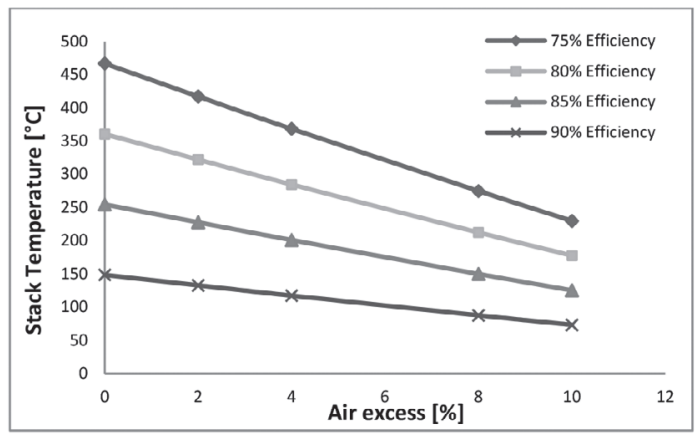

Figure 6. Effect of air excess percentage on stack gas temperature.

Studies have been conducted to evaluate the integrity of the high temperature equipment [18-19], in which critical temperature is identified as $705^{\circ} \mathrm{C}$ to tube wall temperature.

In order to determine the risk for tube and structural damages in the furnace it was necessary to analyze the tube wall temperature (skin tube) data in the process, the temperatures are reported in Table 5.

Table 5. Data report of tube wall temperature

\begin{tabular}{|c|c|c|}
\hline $\begin{array}{c}\text { Fuel gas } \\
\text { composition }\end{array}$ & $\begin{array}{c}\text { LHV } \\
\left(\mathbf{B T U}_{\mathbf{f} \mathbf{t}^{\mathbf{3}}}\right)\end{array}$ & $\begin{array}{c}\text { Tube wall } \\
\text { Temperature }\left({ }^{\circ} \mathbf{C}\right)\end{array}$ \\
\hline 1 & 1131.90 & 624.44 \\
\hline 2 & 1068.10 & 566.66 \\
\hline 3 & 831.8 & 285 \\
\hline 4 & 862.8 & 307.22 \\
\hline 5 & 937 & 396.11 \\
\hline 6 & 1147.20 & 687.77 \\
\hline 7 & 860.1 & 310 \\
\hline 8 & 814.1 & 265.55 \\
\hline 9 & 1094.80 & 585.55 \\
\hline 10 & 1080.60 & 571.11 \\
\hline 11 & 893.6 & 373.88 \\
\hline 12 & 916.6 & 377.77 \\
\hline 13 & 1103.40 & 586.66 \\
\hline
\end{tabular}

According to data report, tube wall temperature is not higher than limit temperature $\left(705^{\circ} \mathrm{C}\right)$, but the furnace is exposed to a corrosive environment because gas fuel contained $\mathrm{H}_{2} \mathrm{~S}$.

Mixture $\mathrm{C} 1$ presents $4 \%$ of $\mathrm{H}_{2} \mathrm{~S}$ and $20 \%$ of Hydrogen. This in turn produces aggressive an environment and increased risk for damages by high temperature. At this point is necessary to evaluate combustion efficiency to determine which mixture generates the less impact.
Historical data process showed that combustion efficiency presented values between 60 and $90 \%$, but is affected for changes in gas fuel composition.

Combustion efficiency was evaluated with models presented in this paper (Models I, II, III and IV). Process parameters are shown in Table 6.

Table 6. Process parameters.

\begin{tabular}{|c|c|}
\hline Parameter & Data \\
\hline$\%$ excess $\mathrm{O}_{2}$ & $2 \%$ \\
\hline Gas fuel flow & $6.15 \mathrm{kgmol} / \mathrm{h}$ \\
\hline Heat required by process & $4113238.605 \mathrm{BTU}$ \\
\hline
\end{tabular}

For four representative mixtures (C1, C2, C3 and C4) and natural gas it was calculated the heat supply for process based in its composition, Table 7 presented LHV and heat supply for process.

Table 7. Heat supply for process.

\begin{tabular}{|c|c|c|}
\hline Fuel gas & $\begin{array}{c}\text { LHV (Btu/ } \\
\mathbf{f t}^{\mathbf{3}} \text { ) }\end{array}$ & $\begin{array}{c}\text { Heat supply for process } \\
(\mathbf{B t u} / \mathbf{h})\end{array}$ \\
\hline $\mathrm{NG}$ & 903 & 4839104.56 \\
\hline $\mathrm{C} 1$ & 955 & 5042933.21 \\
\hline $\mathrm{C} 2$ & 1200 & 6294083.303 \\
\hline $\mathrm{C} 3$ & 1530 & 7976800.237 \\
\hline $\mathrm{C} 4$ & 1800 & 9365025.001 \\
\hline
\end{tabular}

Table 8 presented efficiency data calculated by Aspen Hysys.

Mixture C1 presents lower efficiency, which is according to reported by Hsieh and Wildy [2, 13] for fired heater; mixture $\mathrm{C} 1$ has high Hydrogen concentration and is more difficult to control in operation, but it presents higher potential for use due to saving natural gas and lower $\mathrm{CO}_{2}$ emissions.

Table 8. Efficiency data calculated.

\begin{tabular}{|c|c|}
\hline Fuel gas & Efficiency data (\%) \\
\hline NG & 87.7 \\
\hline C1 & 85.8 \\
\hline C2 & 87.5 \\
\hline C 3 & 87.5 \\
\hline C4 & 88.2 \\
\hline
\end{tabular}


Some fired heaters are designed to operate on natural gas, so the efficiency of this equipment is greater when using methane-rich fuel, but using mixtures containing hydrogen can decrease efficiency, although this increases the risk of explosions.

Efficiency process was calculated using four models analyzed in this paper, the results showed that Model I and Model II presented comparative results for the evaluation of combustion efficiency process using fuel with variable composition, but the model I is simpler than model II because it doesn't require knowledge about kinetic reactions, products and reactants thermodynamics data (enthalpy). Thereby, this model is easier to calculate because it only requires stack gas temperature and LHV. However the models I and II do not account for heat losses by radiation and convection to the walls of the combustion chamber. Therefore, these models may be used to compare with another models that assume losses heat.

Model III and IV account for heat losses of 3 and $2 \%$ respectively.

Model III is a rough approach for calculating efficiency combustion process when stack gas temperature, adiabatic flame temperature and air excess data are available, but this model doesn't present a good approximation compared with model I, as show in Figure 7.

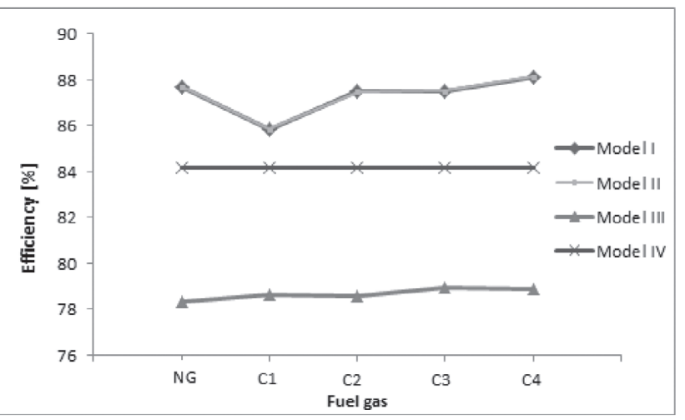

Figure 7. Combustion process efficiency evaluated by four models.

Model IV is an effective approximation for calculation of efficiency combustion process, because it requires knowing only the air excess and stack gas temperature, besides the Figure 7 showed good approximations with the model I, although this model doesn't account for the composition effect in gas mixtures with variable composition.

Finally, considering the number of variables and the influence conditions that can limit the reproducibility of results, it can be suggested that model IV is the choice for the evaluation efficient combustion, although this model should include a correction in the case of fuel gas mixtures with variable composition.

\section{CONCLUSIONS}

The simulation of fuel mixtures in Aspen Hysys helped assess the combustion characteristics by varying the fuel composition, allowing stable ranges for the percentage of energy efficiency and adiabatic temperature. The simulating data agreed with the process data.

The statistical analysis done using software (Statgraphics Centuriun XV.II) allowed establishing a representative mixture of $\mathrm{RG}$; this mixture comprises 8 compounds (methane, ethane, propane, n-butane, ethylene, propylene, hydrogen sulfide and hydrogen), which are the most influential in the combustion process.

Lower stack gas temperatures are presented for high efficiency of combustion and this temperature decreases when air excess percentage is increased.

Fuel mixtures evaluated showed tube wall temperatures within the limits established by the literature to ensure no damage is caused by high temperature.

The models for the efficiency calculation presented in this paper are based on fuel gas that consists mainly of methane, but its effectiveness decreases with gas mixtures of variable composition.

Model IV presents a good approximation to evaluate combustion process efficiency associated with chemical energy that can be converted into heating using only the stack gas temperature, air excess and heat losses. 


\section{REFERENCES}

[1] U.S. Department of Energy. "Industrial Combustion Technology Roadmap. A Technology Roadmap by and for the Industrial Combustion Community”. pp 1-11. Date of visit: February 15, 2013. URL: https:// www1.eere.energy.gov/manufacturing/ industries_technologies/combustion/pdfs/ combustion_roadmap2.pdf

[2] S. Hsieh and G. Jou. "Using Hidrogen-Rich multifuel to improve energy efficiency and reduce $\mathrm{CO}_{2}$ emission for high-energy furnace". Environmental Progress \& Sustainable Energy. Vol. 28 N $^{\circ}$ 1, pp. 83-88. April, 2009. ISSN 1944-7450. DOI: 10.1002/ ep.10347.

[3] F. Johnson and R. David. "Gas Interchangeability Tests-Evaluating the Range of Interchangeability of Vaporized LNG and Natural Gas". GRI-03/0159. April, 2003.

[4] American Gas Association. "White Paper on Natural Gas Interchangeability and Non-Combustion End Use". In R.H. Bob Wilson. pp. 2-72. Date of visit: November 10, 2012. URL: http://www.aga.org/ Kc/OperationsEngineering/gasquality/ Pages/0502NGINTERCHANGE.aspx

[5] H.F. Coward and H.P. Greenwald. "Propagation of Flame in Mixtures of Natural Gas and Air". U.S. Government. Washington DC. USA. 1928.

[6] D. Montaña. "Determinación de las propiedades de combustión e identificación de problemas de intercambiabilidad de las mezclas de gas natural con otros combustibles de refinería". Tesis para optar al grado de magister en ingeniería química. Universidad Industrial de Santander. Bucaramanga, Colombia. 2011.

[7] S. Hsieh and C.J.G. Jou. "Reduction of greenhouse gas emission on a mediumpressure boiler through hydrogen-rich fuel control". Applied Thermal Engineering. Vol. $27 \mathrm{~N}^{\mathrm{o}}$ 17-18, pp. 2924-2928. December, 2007. ISSN: 1359-4311. DOI: $10.1016 / j$. applthermaleng.2006.10.003.

[8] C.L. Lee. and C.J.G. Jou. H.S. "Reduction of nitrogen oxides emissions of a mediumpressure boiler through fuel control”. Aerosol and Air Quality Research. Vol. $6 \mathrm{~N}^{\circ} 2$, pp. 123-133. June, 2006. ISSN: 1680-8584.

[9] C.J.G. Jou. and C.L. Lee C. "Enhancing the performance of a high-pressure cogeneration boiler with waste hydrogen-rich fuel". International Journal of Hydrogen Energy. Vol. $33 \mathrm{~N}^{\mathrm{o}} 20$, pp. 5806-5810. October, 2008. ISSN 0360-3199. DOI: 10.1016/j. ijhydene.2008.05.114.

[10] A.M. Mastral and R. Murillo. "Study of the viability of the process for hydrogen recovery from old tyre oils". Fuel Processing Technology. Vol. $75 \mathrm{~N}^{\circ} 3$, pp. 185-199. March, 2002. ISSN 0378-3820. DOI: 10.1016/ S0378-3820(02)00004-8.

[11] C.L. Lee and S.S. Hou. "Improving costeffectiveness for the furnace in a full-scale refinery plant with reuse of waste tail gas fuel". International Journal of Hidrogen Energy. Vol. 35 N$^{\circ}$ 4, pp. 1797-1802. February, 2010. ISSN 0360-3199. DOI: 10.1016/j. ijhydene.2009.11.130.

[12] T. Rogaume and M. Auzanneau. "The effects of different airflows on the formation of pollutants during waste incineration". Fuel. Vol. $81 \mathrm{~N}^{\circ} 17$, pp. 2277-2288. December, 2002. ISSN 0016-2361. DOI: 10.1016/ S0016-2361(02)00151-5.

[13] F. Wildy. "Fired heater optimization". AMETEK Process Instruments, pp. 2-7. URL: http://www.etaassociates.com/Fired $\% 20$ Heater\%20Optimization\%20ISA\%20AD. pdf. Date of visit: March 20, 2013.

[14] J.C. Serrano. and Y.A. Carranza. "Análisis teórico de la combustión en quemadores de gas natural". Scientia et Technica. Vol. 3 No 29, pp. 139-143. December, 2005. ISSN: 0122-1701.

[15] ASME PTC 4.1. "Fired Steam Generators, Performance Test Code 4". New York, USA. 2008.

[16] C.A. Meza. "Análisis de la eficiencia en la combustión de gas de refinería en hornos industriales tipo cabina, mediante estudio de su comportamiento real". Tesis para optar al grado de Ingeniero Químico. Universidad Industrial de Santander. Bucaramanga, Colombia. 2002.

[17] Tech Engineering. "Fired Heaters" Date update: December 6, 2008. Date of visit: January 25, 2013. URL: http://www. techengineering.it/articles. asp?id=17 
[18] J. Saavedra. "Mecanismo de daño por alta temperatura de un acero HP-40 expuesto al ambiente carburizante característico de un horno de pirólisis de etano para producción de etileno". Tesis para optar al grado de doctor. Universidad Industrial de Santander. Bucaramanga, Colombia. 2012.
[19] J.A. Serna. "Oxidación, carburación y sulfidación de aleaciones ferríticos, $\mathrm{Fe}$ 9Cr-1Mo modificadas en ambientes con hidrocarburos a temperaturas entre $550^{\circ} \mathrm{C}$ y $750{ }^{\circ} \mathrm{C} "$. Tesis para optar al grado de doctor. Universidad Industrial de Santander. Bucaramanga, Colombia. 2003. 